\title{
A Multimodal Analysis of Advertisement of Online Marketplace Shopee
}

\section{Lilis Handayani Napitupulu, Evi Novalin Bako, Nining Rahayu Ars, and Thyrhaya Zein}

Linguistics Study Program, Postgraduate Program, University of Sumatera Utara, Medan, Indonesia

\section{Abstract}

High human mobility demands the world of commerce to be able to provide services and goods quickly according to consumer demand. To overcome this phenomenon, now appears transactions that use the internet media to connect producers and consumers known as online marketplace. This research studies the advertisement in online marketplace named Shopee by using multimodal analysis. Shopee is an online marketplace app for buying and selling on mobile phones with ease and quickly

Corresponding Author: Lilis Handayani Napitupulu lilisnapit@yahoo.com

Received: 13 March 2018 Accepted: 10 April 2018 Published: 19 April 2018

Publishing services provided by Knowledge E

(c) Lilis Handayani Napitupulu et al. This article is distributed under the terms of the

Commons Attribution License, which permits unrestricted use and redistribution provided that the original author and source are credited.

Selection and Peer-review under the responsibility of the AICLL Conference Committee.

\section{G OPEN ACCESS} offering a wide range of products. This research deals with linguistic and visual analysis. This research is focused on the function of the advertisement realized in the offer goods for buyers interested to see and buy that found and dominates in the online marketplace named Shopee. Multimodal analysis method that is used in the research is text verbal analysis theory in language metafunction such as ideational, interpersonal, and textual metafunction by Halliday (1994), while visual text using multimodal analysis by Kress and Van Leuwen $(1996,2006)$ and Cheong $(2004)$. The result of multimodal analysis of advertisement of online marketplace Shopee is described in linguistic and visual analysis.

Keywords: multimodal, metafunctions of language, advertisement, Shopee

\section{Introduction}

In the broadest sense advertisements either persuade or inform receivers in terms of their functionality. The main function of a persuasive advertisement is to persuade the receiver to buy the product. In fact the receiver is directly manipulated to change his/her (consumer) behavior. They present goods in such attractive and appealing appearances to their audience that even junk products will gain some consumers.

It is clear to say that amongst many advertisements produced some are more interesting and take the attention of more viewers than others. These are what we call, for the ease of reference, 'persuasive ads'. In fact an ad is constructed to be persuasive. 
Suppliers of ads use various techniques to construct more persuasive advertisements. Due to its time of occurrence this ad will stay in your mind for a while (they know when to put them). As you see it is a persuasion-making strategy adopted by suppliers which influences their audience either consciously or subconsciously. You may tend to ignore the ad but in reality you do not and it surely influences the choices you make in your shopping. The various characteristics of advertising as identified by Cook (1992: 214) apply to the broad spectrum of advertisements, in whatever form. The features that follow are prototypical of advertisements rather than definitive.

An online marketplace (or online e-commerce marketplace) is a type of e-commerce site where product or service information is provided by multiple third parties, whereas transactions are processed by the marketplace operator. Online marketplaces are the primary type of multichannel ecommerce and can be a way to streamline the production process.

In an online marketplace, consumer transactions are processed by the marketplace operator and then delivered and fulfilled by the participating retailers or wholesalers (often called drop shipping). Other capabilities might include auctioning (forward or reverse), catalogs, ordering, wanted advertisement, trading exchange functionality and capabilities like Shopee, Lazada or Bibli.com. These type of sites allow users to register and sell single items to a large number of items for a "post-selling" fee.

Shopee is a marketplace based mobile commerce app. Shopee is an online shopping container application that focuses more on mobile platforms so people are easier to find, shop, and sell directly on their phones only. Shopee itself has been launched on a limited basis in early 2015 in Southeast Asia, including Singapore, Malaysia, Thailand, Vietnam, Philippines and Taiwan. The platform offers a wide range of products, complemented by secure payment methods, integrated delivery services and innovative social features to make buying and selling more fun, safe and practical. Shopee is an online shopping platform that carries the social concept, where users not only focus on buying and selling alone, but also can interact with other users via instant messaging feature directly.

\section{Literature Review}

We tend to take this for granted that we live in a multimodal society that makes its meanings through the combined use of semiotic resources (e.g. spoken and written language, visual imagery, mathematical symbolism, sculpture, architecture, gesture and other physiological modes). Multimodality refers to the fact that all texts combine and integrate diverse semiotic modalities. This multimodal perspective could be traced 
back to the pioneering work ofscholars such as Gregory Bateson, Ray Birdwhistell, E. T. Hall, A. E. Scheflen and others in the 1950's and 1960's.

However, until the publication of Kress and van Leeuwen"s (2006) Reading Images: The Grammar of Visual Design, the early work of these scholars has been further investigated based on Systemic Functional linguistics and social semiotics. A multimodal text, as a unit of meaning, combines semiotic resources to produce meaning. With development of computer technology in recent years, a large number of multimodal texts with more complex integrations of resources in printed pages come into view. meaning-making in such multimodal texts is dependent on an interplay of allsemiotic resources of which language is only one component.

The Meaning in a multimodal text is realized through the selection of semiotic choices from meaning potentials of all semiotic modes in the text. Social semiotic analysis of multimodal texts is based on M.A.K. Halliday"s (1978) theory of "metafunctions" to identify three distinct but coexisting kinds of meanings that interplay within any text. Metafunctional analysis can be extended beyond the linguistic field there by providing the descriptive basis for all meaning-making practices. Systemic Functional theory provides a social semiotic framework for the analysis of multimodal texts with context-dependent meaning studies and a comprehensive approach to language.

\section{Research Method}

This research uses content analysis method. In this study, the researchers presented descriptively multimodal text on shopkeeping ads with visual metaphysical analysis of Kress and van Leeuwen $(1996,2006)$ based on Halliday $(1985,2004)$ of the metaphysis theory and the logical intersemiotic relationship between verbal and visual texts with the Liu model Y and O'Halloran (2009). The data that will be analyzed in this research is verbal and visual text data/picture contained in shopee advertisement. The data were analyzed by Kress and van Leeuwen's visual metaphone theory $(1996,2006)$. Data analysis is the next step after the data collected. Data that is ready and already recorded in the data card and classified systematically according to research interests then analyzed. In analyzing the data, researchers used interactive models from Miles, Huberman and Saldana (2014). 


\section{Discussion}

The results of this study consisted of an explanation of the meta-function analysisvisual Kress and van Leeuwen based on Halliday's metaphy in the textmultimodal on the advertisement of online marketplace "shopee" as well as inter-semiotic relationships between verbal and visual texts. Once data is selected based on data that may represent visual meta-function analysis, not all data meet the ideational, interpersonal and textual components as proposed by Kress and van Leeuwen (1996, 2006), only a few data have them. The following is a visual metaphunction in multimodal text on the advertisement of online marketplace "shopee" and the logical inter-semiotic relationship between verbal texts and visual texts in conveying meaning.

\subsection{Linguistic analysis}

Linguistic analysis in shopee based on the language metafunctions: experimental, interpersonal, textual (Halliday, 2004). The analysis is focused on the verbal elements contained in this ad.

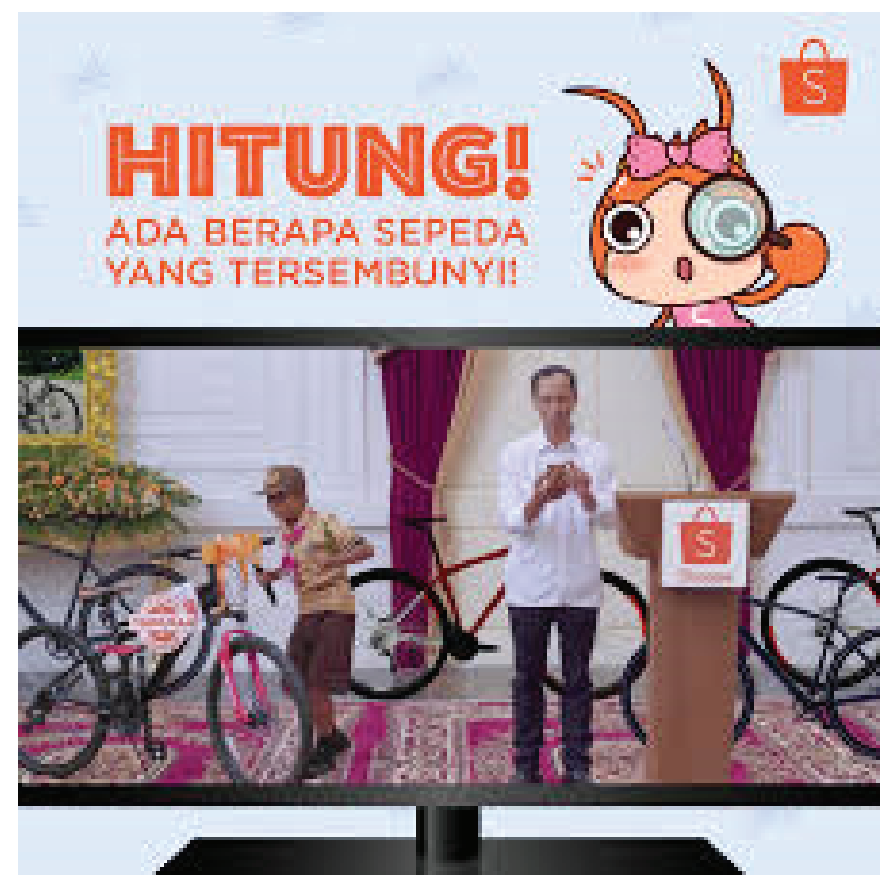

Picture 1

According to the experimental function, the clause in (1) uses a material process using a participant ie goal. determination of participants as a goal because "bicycle" is a goal, not a participant actors or actors. Circumcision which is the description according to the intercellar function, the clause in (1) is a statement realized with a declarative 
TABLE 1: Hitung ada berapa sepeda yang tersembunyi.

Hitung!
Meterial
Process
Subject
Mood
Theme

Ada
berapa
Predicator

Sepeda
Goal

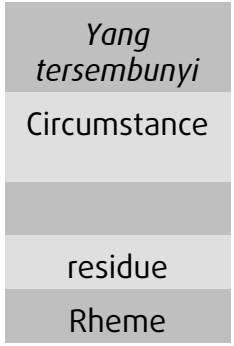

mood system. thus the role of this clause in exchanging experience is to inform. this clause informs viewers that there are now some hidden bicycles

TABLE 2: Sepeda baru ni!.

\begin{tabular}{l|c}
\begin{tabular}{l|c} 
Sepeda \\
Goal
\end{tabular} & $\begin{array}{c}\text { Baru } \\
\text { Circumstance }\end{array}$ \\
\hline mooject & Residue \\
Theme & Rheme \\
\hline
\end{tabular}

According to the experimental function, the clause in (2) Not uses a process and it just uses a participant ie goal. determination of participants as a goal because "bicycle" is a goal. "baru" is an Circumcision which is the description according to the intercellar function, the clause in (2) is a statement realized with a declarative mood system. thus the role of this clause in exchanging experience is to inform. this clause informs viewers that there are now some hidden bicycles.

TABLE 3: di shopee pipipipi.

Di Shopee pipipipi
Circumstance
Residue
Theme

According to the experimental function, the clause in (3) Not uses a process and it just uses a Circumcision which is the description according to the intercellar function.

TABLE 4: beli sepeda dadadadda.

Beli
Material Process
Mood
Theme
Sepeda Goal Residu Rheme 
According to the experimental function, the clause in (4) uses a material process "beli". determination of participants as a goal because "bicycle" is a goal, not a participant actors or actors.

TABLE 5: beli semua mua mua ma.

\begin{tabular}{|l|c|}
\hline Beli & Semua mua mua \\
\hline Material Process & Goal \\
\hline Mood & Residue \\
\hline Thema & Rheme \\
\hline
\end{tabular}

According to the experimental function, the clause in (5) uses a material process "beli". determination of participants as a goal because "semua" is a goal, not a participant actors or actors.

TABLE 6: beli baju ju ju ju.

\begin{tabular}{|l|c|}
\hline Beli & baju juju ju \\
\hline Material Process & Goal \\
\hline Mood & Residue \\
\hline Theme & Rheme \\
\hline
\end{tabular}

According to the experimental function, the clause in (6) uses a material process "beli". determination of participants as a goal because "baju" is a goal, not a participant actors or actors.

According to the experimental function, the clauses in (2) to 6 use a material process using a participant ie goal. circumcision which is the description. according to the intercellar function, the clauses in (2) to 6 represent a statement realized with a declarative mood system. thus the role of this clause in exchanging experience is to inform. this clause informs viewers that there are now some hidden bicycles.

Based on the results of the above analysis it is found that the material process with frequency presentation (100\%) dominates the type of process contained in the linguistic element, indicating that no other process is contained in the ad shopee With regard to the textual function, the type of theme used is dorninan which is commonly used. It was noted that TIM was used 4 times (66.67\%).

\subsection{Visual analysis}

Visual analysis of advertisement Shopee apply with theory of multimodal and special to analyze structure generic.

Visual analysis [1] Look at this Picture below 


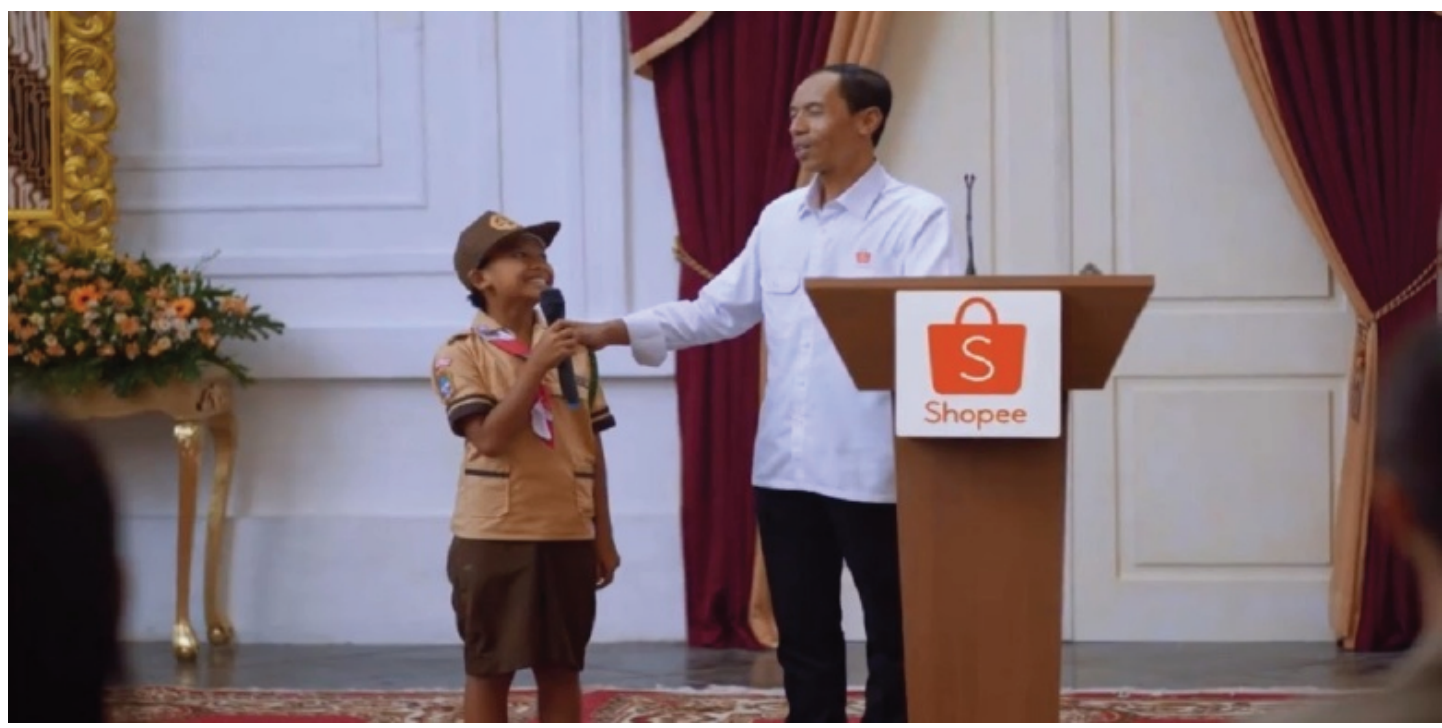

Picture 2

In the picture above shows a child who successfully answered Mr. Jokowi's question and asked for his bike gift, Visual image, this ad displays 19 seconds of the child's request process. In general, the background features selected colors that form the core of the image you want to display and are dominated by the orange image that is the shopee's symbol itself.

\subsection{Generic structure analysis}

Based on the results of the analysis, it was found that the shopee's ads were formed by the following generic structures: (1) the core, consisting of the center of attention and the complementary center of attention; (2) appearance, which is implicit and congruent; (3) symbol (verbal); (4) announcement; (5) emblem (Nonverbal); and (6) labels the core of this ad is the shopee cart image that zooms in larger than all the images in the image. and located in the middle, this to give the impression that the importance of the image. Besides the center of attention is the writing "free postage"

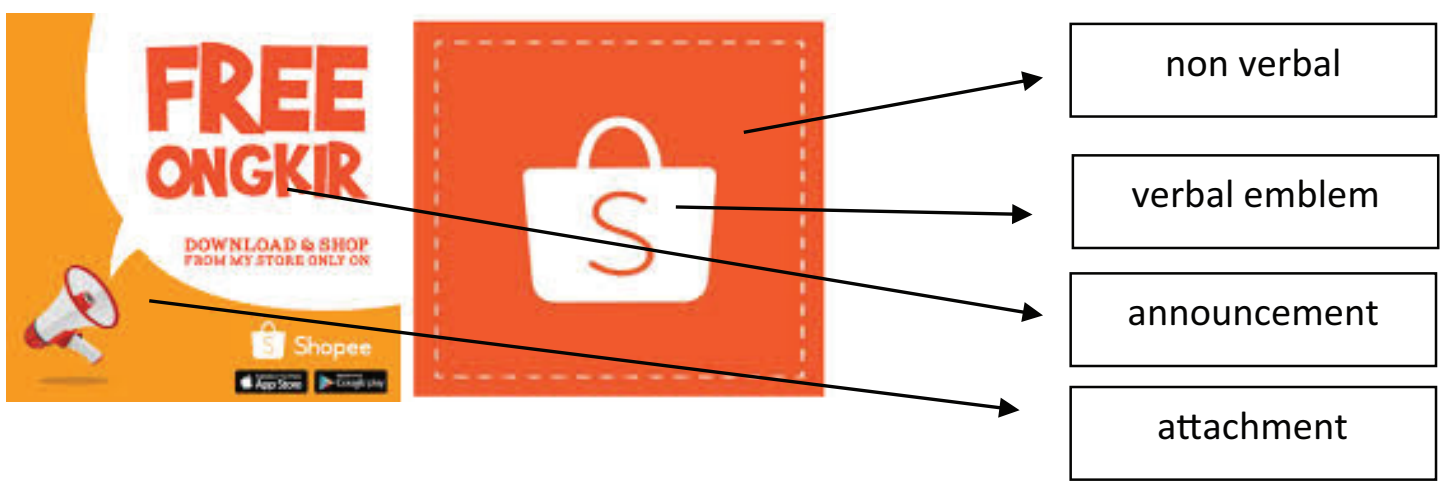




\section{Conclusions}

This shopee ad shows enough information about what people want from an onlineshop like a shopee, ie Order speed and free language shipping that is done through spoken language and written language makes the audience more understanding about what is being promoted. Short duration but contains a whole message that is important to deliver makes this ad a distinct impression for the audience. This ad covers all five aspects of the system semiotik multimodal, ie linguistic aspects, visual, audio, gestural, and location. These five aspects are integrated to convey the essence of message, which advertises online market shopee. Based on the results of the above analysis it is found that the material process with frequency presentation (100\%) dominates the type of process contained in the linguistic element, indicating that no other process is contained in the ad shopee With regard to the textual function, the type of theme used is dorninan which is commonly used. It was noted that TIM was used 4 times $(66.67 \%)$. Based on the results of the analysis, it was found that the shopee's ads were formed by the following generic structures: (1) the core, consisting of the center of attention and the complementary center of attention; (2) appearance, which is implicit and congruent; (3) symbol (verbal); (4) announcement; (5) emblem (Nonverbal); and (6) labels the core of this ad is the shopee cart image that zooms in larger than all the images in the image. and located in the middle, this to give the impression that the importance of the image.

\section{References}

[1] Anstey, M and Bull, G. (2010). Helping Teachers to Explore Multimodal Texts. In Curriculum \& Leadership Journal, Volume 8 Issue 16, ISSN: 1448-0743 http://www.curriculum.edu.au/leader/vol8_no16,29838.html?issuelD=12141

[2] Cook, G. (1992). The Discourse of Advertising. London: Routledge and Kegan Paul.

[3] Halliday, M. A. K. (1994). An Introduction to Functional Grammar (2nd Edition). London and New York: Arnold (A Member of the Hodder Headline Group).

[4] Halliday, M. A. K. (2002). Linguistic Studies of Text and Discourse (Edited by Jonathan Webster). London and New York: Continuum.

[5] Hermawan, B. (2012). Multimodality: Menafsir Verbal, Membaca Gambar, dan Memahami Teks Analisa Jurnal FPBS UPI [in press].

[6] ledema, R. (2003). 'Multimodality, Resemioticization: Extending the Analysis of Discourse as a Multisemiotic Practice', Visual Communication 2.

[7] Kress, G. and Leeuwen, T. (2001). Multimodal Discourse. London: Arnold. 
[8] Kress, G. and Leeuwen, T. (2006). Reading Images: the Grammar of Visual Design. London: Routledge.

[9] Leeuwen, T. (2004). Ten reasons why linguists should pay attention to visual communication. In P. Levine \& R. Scollon (Eds.), Discourse \& Technology. Multimodal discourse analysis (pp.10-19). Georgetown, Washington, D.C.: Georgetown University Press.

[10] Leeuwen, T. (2006). Sound in Perspective. In Adam Jaworski and Nikolas Coupland (Eds.), The Discourse Reader (2nd ed.),(pp. 179-193). New York: Routledge.

[11] Liu, Y., and O'Halloran, K. L. (2009). Intersemiotic Texture: Analyzing Cohesive Devices between Language and Images. Social Semiotics, 19 (4), 367-387.

[12] Miles, M. B., Huberman, A.M., and Saldana, J. (2014). Qualitative Data Analysis: A Methods Sourcebook Ed 3. USA: Sage Publications.

[13] Miles, M.B. dan Huberman, A.M. (1984). Analisis Data Kualitatif. Jakarta: Universitas Indonesia Press

[14] Mulyana. (2005). Kajian Wocana. Yogyakarta: Tiara Wacana.

[15] Ningsih, E. F., Tallapessy, A., dan Setiarini, R. (2014). Construing Ideational Meaning in Electronics Devices Advertisements in Jawa Pos: a systemic Functional Linguistic Multimodal Discourse Analysis. Publika Budaya. Vol.2: 6- 14.

[16] Norris, S. (2004). Analyzing Multimodal Interaction. A Methodological Framework. New York: Routledge.

[17] Nurlela. (2010). Refresentasi Leksikogramatika Teks Pidato Kenegaraan Presiden Soeharto dan Presiden Susilo Bambang Yodhoyono. Dissertation. Medan: University of Sumatera Utara.

[18] O'Halloran, K., Tan, S., Smith, B. and Podlasov, A. (2010). Challenges in designing digital interfaces for the study of multimodal phenomena. Information Design Journal 18 (1), 2-21.

[19] Pujadiharja, E. (2013). Kajian Multimodal Teks Tubuh Perempuan Dalam Film Dokumenter Nona Nyonya? Karya Lucky Kuswandi. Visualita. Vol. 5: 44- 64.

[20] Sinar, T. S. (2014). Teori dan Analisis Wacana: Pendekatan Linguistik Sistemik Fungsional. Medan: Mitra. 